\title{
Diamond nucleation barrier and melting relations for Ol-Opx-Cpx- Grt-carbonate system: syngenesis of diamond and silicate minerals
}

\author{
A.V. Bobrov ${ }^{1,2}$ and Yu.A. Litvin ${ }^{2}$ \\ ${ }^{1}$ Dept. Petrology, Geological Faculty, Moscow State University, Moscow, Russia \\ ${ }^{2}$ Institute of Experimental Mineralogy, Chernogolovka, Russia
}

The solution of the problem of diamond genesis in the Earth mantle should be mostly based on the chemical composition of parental media, which is evident from syngenetic inclusions in diamonds from kimberlites and lamproites. Fragments of parental media as silicate minerals demonstrate their variable paragenetic associations, from olivine-bearing peridotite and pyroxenite to eclogite and grospydite including coesitebearing varieties (e.g., Meyer, 1987). Numerous studies of crystalline inclusions in diamonds demonstrate that the most of them were formed at depths of 150-250 $\mathrm{km}$, in a temperature range of $900-1300^{\circ} \mathrm{C}$ (e.g., Taylor, Anand, 2004).

Finds of fluid carbonatite inclusions enriched in $\mathrm{H}_{2} \mathrm{O}$, $\mathrm{CO}_{2}, \mathrm{SiO}_{2}, \mathrm{~K}_{2} \mathrm{O}$ in diamonds, which have high internal pressure (4-7 GPa) (e.g., Navon, 1991; Schrauder, Navon, 1994), confirm the idea of strongly compressed parental multi-component carbonate-silicate melts with dissolved carbon and variable concentrations of minor (oxides, phosphates, chlorides, sulfides, metals, carbides, etc.) components (Litvin, 2007). In this connection mineralogical data solely does not allow to establish the chemical nature and composition of mantle media, which may provide the diamond formation. Such media may be established exclusively in experiments at high pressures and temperatures using the criteria of their efficiency for diamond nucleation and syngenesis of diamonds and their inclusions. In this paper we demonstrate diamondforming efficiency of peridotite-carbonate and eclogitecarbonate melts in experiments at 7.0-8.5 GPa and $1200-1800^{\circ} \mathrm{C}$.

\section{Peridotite-carbonate system}

We simulated crystallization of diamonds in melts with dissolved carbon (graphite) and variable compositions of model peridotite [60 wt.\% olivine (Ol), 16 wt.\% orthopyroxene (Opx), 12 wt.\% clinopyroxene (Cpx), 12 wt.\% garnet (Grt)] with carbonate of dolomite composition $\left(\mathrm{CaCO}_{3} \cdot \mathrm{MgCO}_{3}\right), \mathrm{K}_{2} \mathrm{CO}_{3}$, and also multicomponent K-Na-Ca-Mg-Fe-carbonatite [Carb; the composition is taken from (Schrauder, Navon, 1994)]. Carbonate-silicate melts in all experiments performed at PT-conditions of diamond stability are completely soluble. Concentration barriers of diamond nucleation
(CBDN) were estimated at a pressure of $8.5 \mathrm{GPa}$ for variable concentrations of silicate and carbonate components in parental melts: 25,30 , and $30 \mathrm{wt} \%$ of silicate components for $\mathrm{CaCO}_{3} \cdot \mathrm{MgCO}_{3}, \mathrm{~K}_{2} \mathrm{CO}_{3}$, and model carbonatite, respectively (Figs. 1, 2). At higher silicate concentrations in carbonate-silicate melts, diamond grows only on seed being accompanied by thermodynamically metastable graphite phase.

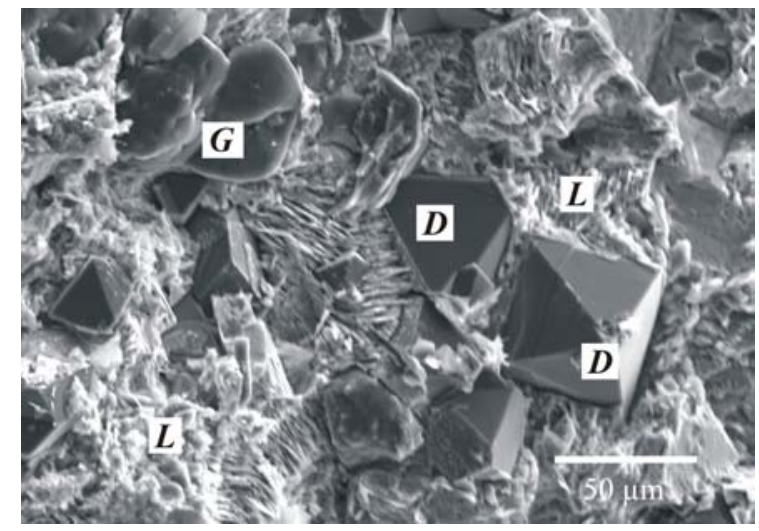

Fig. 1 SEI of diamond and graphite crystals in quenched silicate-carbonate melt at CBNA (30 wt.\% peridotite-70 wt. $\% \mathrm{~K}-\mathrm{Na}-\mathrm{Mg}-\mathrm{Ca}-\mathrm{Fe}$ carbonate). $\mathrm{P}=8.5$ $\mathrm{GPa} ; \mathrm{T}=1770^{\circ} \mathrm{C}$; run duration $10 \mathrm{~min}$.

The appearance of silicate minerals syngenetic to diamond in the studied diamond-forming melts was established in special run series at $\mathrm{P}=7.0 \mathrm{GPa}$ and $\mathrm{T}=$ $1200-1800^{\circ} \mathrm{C}$ for the composition of peridotite ${ }_{30}$ carbonate $_{70}$ (wt.\%), which corresponds to $\mathrm{CBDN}$. Ol is a liquidus phase in the system with $\left(\mathrm{CaCO}_{3} \cdot \mathrm{MgCO}_{3}\right)$; at $\mathrm{T}<1700^{\circ} \mathrm{C}$, an association of $\mathrm{Cpx}+\mathrm{Ol}+$ carbonatesilicate melt (L) is stable; at $1600^{\circ} \mathrm{C}$, Grt is added. The prevalence of Cpx over other silicates was established for this system; none of the runs demonstrated the presence of Opx. It is assumed that in $\mathrm{CaCO}_{3}$-rich systems Opx enters into reaction like $2 \mathrm{MgSiO}_{3}+$ $\mathrm{CaCO}_{3} \rightarrow \mathrm{CaMgSi}_{2} \mathrm{O}_{6}+\mathrm{MgCO}_{3}$ and practically is not presented as a proper phase. In the system of peridotite-alkali carbonate $\left(\mathrm{K}_{2} \mathrm{CO}_{3}\right)$ the following assemblages are established: $\mathrm{Opx}(\mathrm{Ol})+\mathrm{L}\left(1800^{\circ} \mathrm{C}\right)$; $\mathrm{Opx}+\mathrm{X}$ phase $+\mathrm{L}\left(1500^{\circ} \mathrm{C}\right) ; \mathrm{Opx}+\mathrm{Ol}+$ carbonate + $\mathrm{L}\left(1300^{\circ} \mathrm{C}\right), \mathrm{Opx}+\mathrm{Ol}+$ wadeite + carbonate $\left(1200^{\circ} \mathrm{C}\right)$. For the first time iron admixture was established in phase $\mathrm{X}$, which was recently synthesized in some 
experimental studies of amphibole and phlogopite stability at $\mathrm{T}=1150-1400^{\circ} \mathrm{C}$ and $\mathrm{P}=9-17 \mathrm{GPa}$ (e.g., Luth, 1997). The composition of $\mathrm{X}$ phase may be expressed by the following formula: $\left(\mathrm{K}_{1.31} \mathrm{Na}_{0.02} \mathrm{Ca}_{0.01}\right)\left(\mathrm{Mg}_{1.50} \mathrm{Fe}^{3+}{ }_{0.37} \mathrm{Al}_{0.05} \mathrm{Ti}_{0.01}\right)\left[\mathrm{Si}_{2} \mathrm{O}_{7}\right] \mathrm{H}_{0.35}$. Crystallization of melts with model multi-component (K-Na-Ca-Mg-Fe) carbonatite proceeds with the following change of mineral parageneses as the temperature decreases: $\mathrm{Ol}+\mathrm{L} \rightarrow \mathrm{Ol}+\mathrm{Cpx}(\mathrm{Grt})+\mathrm{L}$ $\rightarrow \mathrm{Ol}+\mathrm{Cpx}$ (Grt) + carbonate (Fig. 3). In principle, the appearance of Opx is possible in this system (shown by dotted line), but only if initial peridotite is enriched in this component and alkali carbonate $\left(\mathrm{K}_{2} \mathrm{CO}_{3}\right)$ essentially prevail over $\mathrm{CaCO}_{3}$ among carbonate phases.

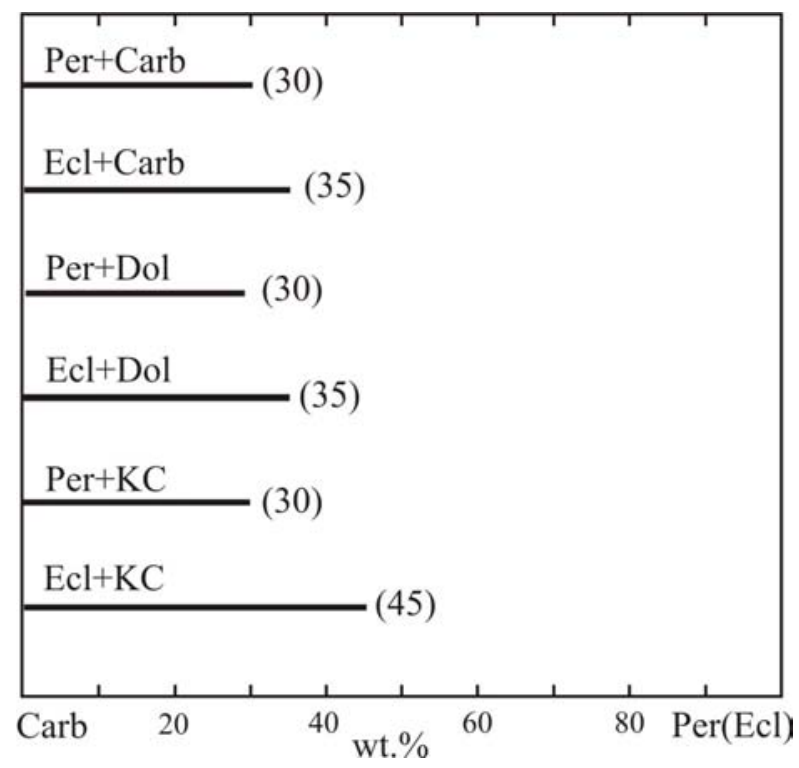

Fig. 2 Concentration barriers of diamond nucleation $(\mathrm{CBDN})$ in the studied silicate-carbonate systems. Per $=$ peridotite; $\mathrm{Ecl}=$ eclogite $;$ Carb = multi-component K-Na-Mg-Ca-Fe carbonate (Schrauder, Navon, 1994); $\mathrm{Dol}=\mathrm{CaCO}_{3} \cdot \mathrm{MgCO}_{3} ; \mathrm{KC}=\mathrm{K}_{2} \mathrm{CO}_{3}$.

\section{Eclogite-carbonate system}

In this study we simulated crystallization of diamonds in melts with variable compositions of model eclogite [50 wt.\% clinopyroxene (Cpx), 50 wt.\% garnet (Grt)] with $\mathrm{CaCO}_{3} \cdot \mathrm{MgCO}_{3}, \mathrm{~K}_{2} \mathrm{CO}_{3}$, and multi-component $\mathrm{K}$ $\mathrm{Na}-\mathrm{Ca}-\mathrm{Mg}$-Fe-carbonatite (Schrauder, Navon, 1994). CBDNs estimated at a pressure of $8.5 \mathrm{GPa}$ and $1800^{\circ} \mathrm{C}$ for variable concentrations of silicate and carbonate components in parental melts were 45 and $35 \mathrm{wt} \%$ of silicate components for $\mathrm{K}_{2} \mathrm{CO}_{3}$ and model carbonatite, respectively (Fig. 2). As evident from the diagram, CBDNs in the eclogite-carbonate system are closer to silicate components in comparison with the peridotitecarbonate system.
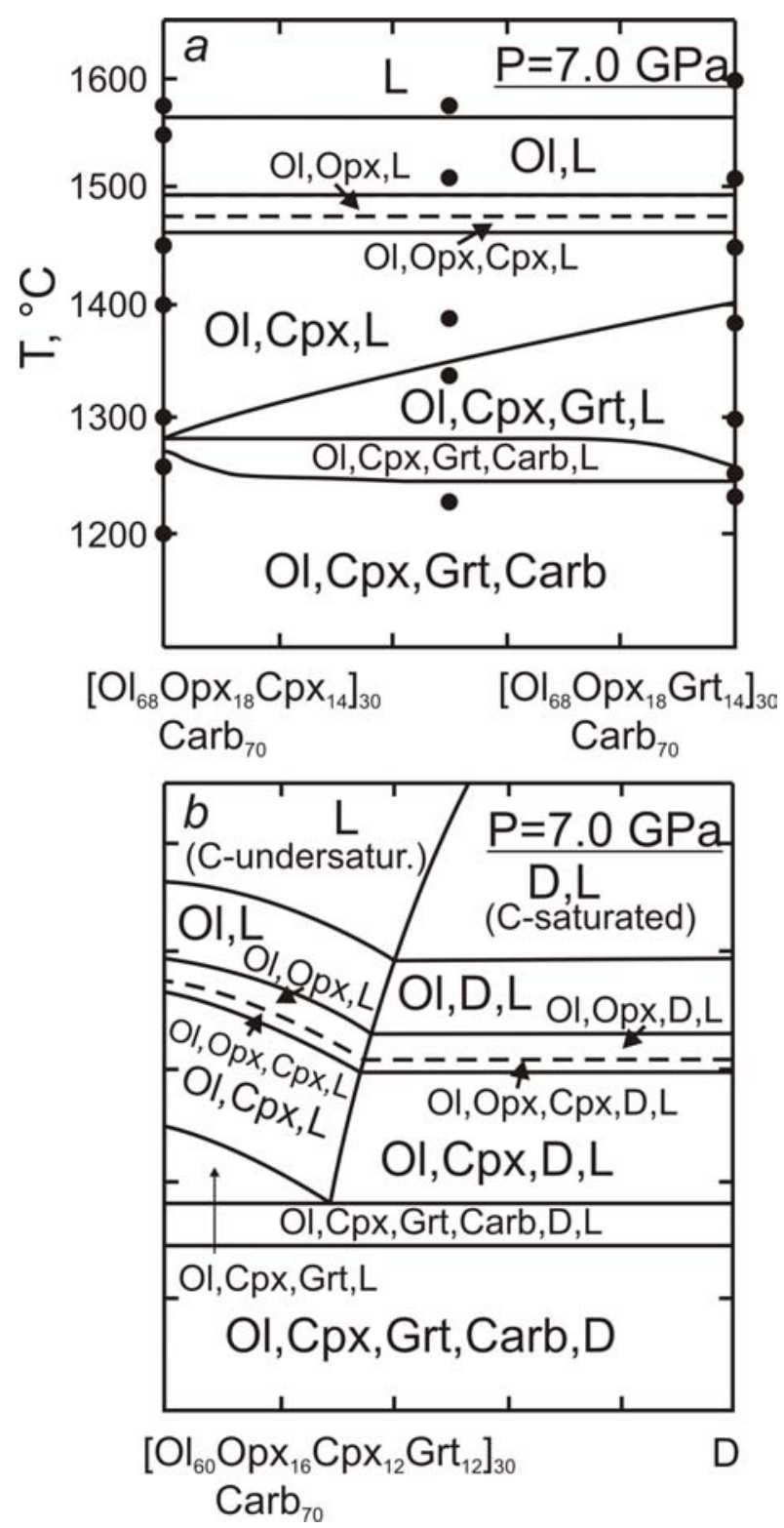

Fig. 3 Scheme of melting relations (a) and diagram of syngenesis of diamond (D) and its silicate and carbonate inclusions $(b)$ in peridotite-carbonate system at CBDN (30 wt.\% peridotite-70 wt.\% K-Na-Mg-CaFe carbonate).

Melting relations in the eclogite-carbonate diamondforming systems were studieded in special run series at $\mathrm{P}=7.0 \mathrm{GPa}$ and $\mathrm{T}=1200-1800^{\circ} \mathrm{C}$ for the composition of eclogite en $_{35}$ - multi-component carbonate 65 (wt.\%). Fig. 4 demonstrates melting relations in this eclogitecarbonatite system at $\mathrm{P}=7.0 \mathrm{GPa}$. In clinopyroxenerich part of the system, at a temperature above $1600^{\circ} \mathrm{C}$, we obtained fine-grained aggregate of skeletal pyroxene, carbonate and phlogopite crystals, which was interpreted as a quenched carbonate-silicate melt. At $1600^{\circ} \mathrm{C}$ the first liquidus mineral, $\mathrm{Cpx}$, appears; further increase of temperature $\left(\sim 1380^{\circ} \mathrm{C}\right)$ results in addition of Carb. At a temperature of $1200^{\circ} \mathrm{C}$ and lower we observed an aggregate of subidiomorphic crystals of pyroxene, carbonate and minor garnet, with 
no signs of quench textures, that points on the solidus of the system.

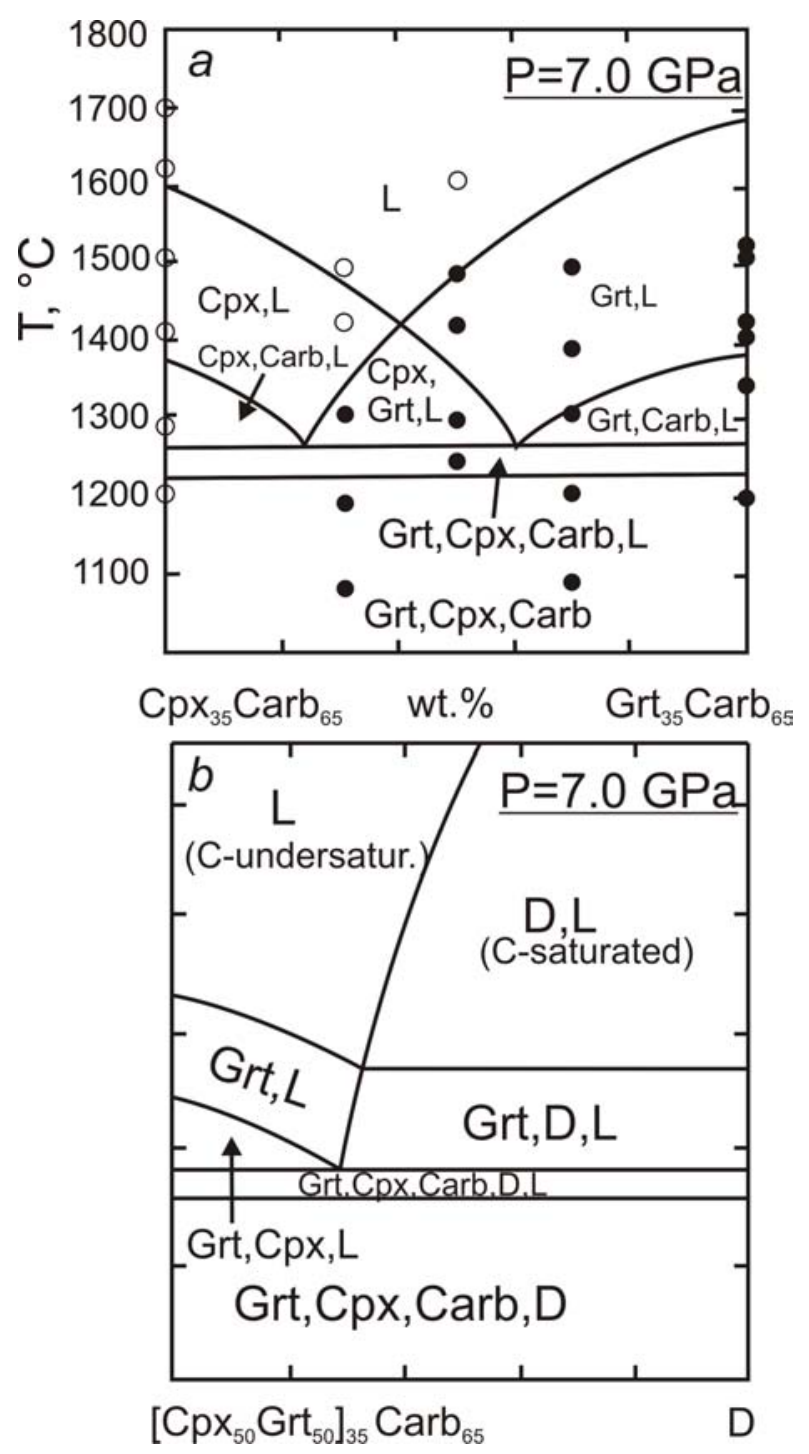

Fig. 4 Scheme of melting relations $(a)$ and diagram of syngenesis of diamond (D) and its silicate and carbonate inclusions $(b)$ in the eclogite-carbonate system at CBDN (35 wt.\% eclogite-65 wt.\% K-Na$\mathrm{Mg}-\mathrm{Ca}-\mathrm{Fe}$ carbonate).

The increase of garnet content in the starting materials results in the decrease of the temperature of pyroxene crystallization, so that at $30 \mathrm{wt} \%$ Grt, pyroxene first appears at a temperature of $1420^{\circ} \mathrm{C}$. With further increase of garnet concentration, we established a change of liquidus mineral: at 50 wt.\% Grt, crystallization of garnet from carbonate-silicate melts was observed. Liquidus field of garnet on the scheme (Fig. 4) is quite wide and spreads over the concentration of garnet in starting materials from $\sim 40$ to $100 \mathrm{wt} \%$ Grt, within the temperature range from $\sim 1600$ to $\sim 1250^{\circ} \mathrm{C}$. As this takes place, garnet concentration in experimental samples increases from 5 to $20-25 \%$ with a temperature decrease. In near-solidus area three-phase assemblage of $\mathrm{Cpx}+\mathrm{Grt}+\mathrm{L}$ appears being replaced with an association of $\mathrm{Grt}+\mathrm{Carb}+\mathrm{L}$ with an increase of garnet content in the system. Finally in one of the runs $\left(1250^{\circ} \mathrm{C}\right)$ we established a four-phase assemblage $\mathrm{Grt}+\mathrm{Cpx}+\mathrm{Carb}+\mathrm{L}$ that is typical for multicomponent system and shown in Fig. 4 as a narrow field. Subsolidus mineral aggregate of $\mathrm{Grt}+\mathrm{Cpx}+\mathrm{Carb}$ was formed below this field in the whole range of starting compositions.

\section{Conclusion}

The results obtained prove the carbonatite (carbonatesilicate) model of diamond genesis and point on theoretical possibility of crystallization of peridotitic and eclogitic silicate minerals syngenetically to diamond in silicate-carbonate melts under PTconditions of diamond stability.

The study was supported by the Russian Foundation for Basic Research (project no. 08-05-00110), grant of the President of Russian Federation (NSh5367.2008.5), Program of the Presidium of the Russian Academy of Sciences P9 "Study of matter under extreme conditions", and INTAS grant no. 051000008-7927 "Diamond and graphite in carbonate magmas".

\section{References}

Litvin, Yu.A., 2007. High pressure mineralogy of diamond genesis. In: Advances in High-Pressure Mineralogy (edited by E. Ohtani). The Geological Society of America, 421, 83-104.

Luth, R.W., 1997. Experimental study of the system phlogopite-diopside from 3.5 to $17 \mathrm{GPa}$. American Mineralogist, 1997, 82, 1198-1209.

Meyer, H.O.A, 1987. Inclusions in diamonds. Mantle Xenoliths, 501-522.

Navon O., 1991. High internal pressures in diamond fluid inclusions determined by infrared absorption. Nature, $335,746-748$.

Schrauder, M., Navon, O., 1994. Hydrous and carbonatitic mantle fluids in fibrous diamonds from Jwaneng, Botswana. Geochimica et Cosmochimica Acta, 58, 761-771.

Taylor, L.A., Anand, M., 2004. Diamonds: time capsules from the Siberian mantle. Chemie der Erde, 64, 1-74. 